\title{
28. 野田喜一：アクリナミンの加水分解反應速度に就いて
}

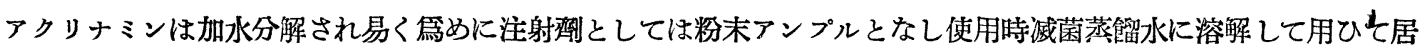
る. 著者はアクリナミンの鹽が注射齊として水溶夜にして使用し得るか不かを檢討せんとした 然して加水分解に關 主る明確なる文献記載無き狀況に鑑み其の分解速度を測定した.アリリナミンの監は結晶其䱾を保存する場合, 長時 間例へば著者の經驗範園少くとも二年位ては熔融黑督變化は認められない. 水溶液の保存の場合は極めて徐々に 2-

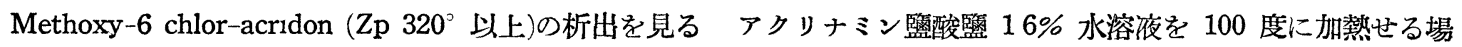
合 1 時間約 $1 \%, 2$ 時間約 $8 \%, 9$ 時間約 $26 \%$ 時間約のアクナミン監酸鹽が分解し, 此の場合の $\mathrm{pH}$ は 4.5 より 52 に變化する.

ヌアクリナミンの加水分解成績物を檢する䉆, アクリナミン鹽酸鹽の水溶夜を加熱し析出する 2-Methoxy-6-chloracridon (2) を除去せる母夜より未分解のアクリナミン監酸鹽と共に 1-Diäthylamino-4-amıno-pentan を其の金複

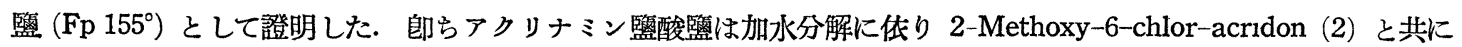
1-Diathylamino-4-aminopentan (3) を生成し, 之か爲 $\mathrm{pH}$ は漸炏增大寸るものと考へられる.

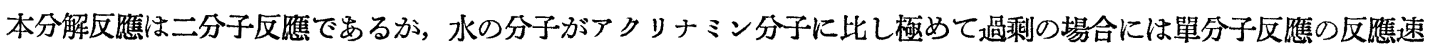
度恒數式 $\left(\mathrm{K}=\frac{1}{t} \times 2.3 \times \log \frac{a}{a-x}\right)$ に一致する數值を與へると考へられる. 故に著者は本反㕍の $\mathrm{pH}$ を定ならしむる

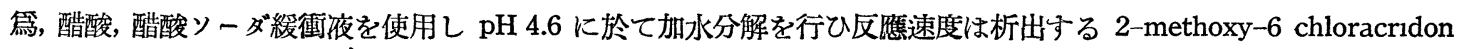
の重量により追跡した 即方 $055 \%$ 醋酸 $200 \mathrm{cc}$ にアクリナミン鹽酸監 $\left(\mathrm{C}_{23} \mathrm{H}_{30} \mathrm{ON} \mathrm{ON}_{3} \mathrm{Cl} \cdot 2 \mathrm{HCl} \cdot 2 \mathrm{H}_{2} \mathrm{O}\right) 5 \mathrm{~g}$ を溶解，之 に醋酸ソーダ $3.43 \mathrm{~g}$ を加一て $100^{\circ}$ に於て加水分解を行ひたる結果は次表の如くであつて本均值 $\mathrm{K}=113 \times 10^{-3}$ (分) なる分解速度恒數を測定し得た 本恒數は任意の單位時間內 (1 分)に分解する率は所在の未變化原料の $0.11 \%$ です る事を意味する. $100^{\circ}, \mathrm{pH} 46$ の場合.

$$
\mathrm{K}=\frac{1}{t} \times 23 \times \log \frac{a}{a-x}
$$

$\mathrm{K}$ 分解速度恒數. $\mathrm{t}$ 時間 (單位分) $\mathrm{a}$ アクリナミン初濃度 (500mg). $x$ 2-Methoxy-6-chlor-acridon 量より換 算せるアクリ゙ナミン量.

\begin{tabular}{|c|c|c|c|c|}
\hline$t_{\mathrm{m} 1 \mathrm{n}}$ & $x_{\mathrm{mg}}$ & $a-x_{\mathrm{mg}}$ & $\log \frac{a}{a-x}$ & $\mathrm{~K}_{\mathrm{min}}$ \\
\hline 60 & 3685 & 46315 & 003325 & $127 \times 10^{-3}$ \\
\hline 120 & 712.5 & 42875 & · $\quad 006677$ & $1.28 \times 10^{-3}$ \\
\hline 180 & 9565 & 40435 & 0.09222 & $1.18 \times 10^{-3}$ \\
\hline 300 & 1403.0 & 35970 & 014303 & $110 \times 10^{-3}$ \\
\hline 360 & 16320 & 33680 & 017160 & $110 \times 10^{-3}$ \\
\hline 420 & 18320 & 31680 & 019818 & $108 \times 10^{-3}$ \\
\hline 480 & 20300 & 29700 & 0.22621 & $108 \times 10^{-3}$ \\
\hline 540 & 21880 & 28120 & 024995 & $106 \times 10^{-3}$ \\
\hline 600 & 2354.0 & 26460 & 0.27638 & $106 \times 10^{-3}$ \\
\hline
\end{tabular}

本均 $113 \times 10^{-3}$

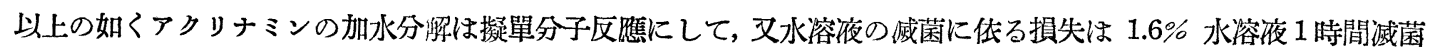
の場合 $1 \%$ に過ぎい. 節ち効力の損耗も $1 \%$ に過きさるが故に水溶夜アンプルの實用も考慮する必要が岗ると考 へる

本研究は終始石福少將閣下並に津田助敉授の御指導に依り行はれたもので, 茲に深甚の謝意を表する次第である. 


\section{1）アクリナミン監酸監の分解生成物}

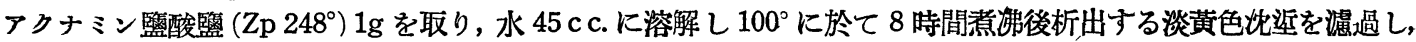
濾夜と沈集に分けて檢討す.

化货 メタノール，アセトンに難溶水醋に稍可溶にして，Zp 320 以上なり．之を 2-Methoxy-69-dichloracridın の加水分解に依り合成せる 2-Methoxy-6-chloracridon（Zp 320 以上) と混融せる倞融點降下を認めす 同 一物質なることを確認す。

濾夜 滤夜は炭酸アルカリにてアルカリ性とせるにアクリナミン監基の沈泝析出す。濾去後濾液に更に炭酸アルカ りを飽和せるに盛にアミン臭を發し上層に㹨狀物析出す 之をエーテルにて振偒し, 油分をエーテル層に移 項し，エーテルを櫭去後殘存せる油狀物を盬化金により金監とせるに Fp $155^{\circ}$ の針狀晶を得 之を新に合成

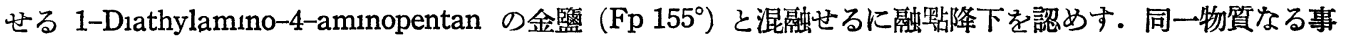
を確認す。

陸軍軍醫學校藥學敉室（昭和 19 年 5 月 11 日受理） 